\title{
A promising and simple method to quantify soil/manure mixing on beef feedlot pens
}

\author{
Chris Pratt ${ }^{\mathrm{A}, \mathrm{B}}$, Matthew Redding ${ }^{\mathrm{A}}$ and Jaye Hill ${ }^{\mathrm{A}}$ \\ A Department of Agriculture, Fisheries and Forestry, 203 Tor Street, Toowoomba, Qld 4350, Australia. \\ ${ }^{B}$ Corresponding author. Email: christopher.pratt@daff.qld.gov.au
}

\begin{abstract}
On beef cattle feed pen surfaces, fresh and decayed manure is mixed with base rock or soil (base). Quantifying this mixing has beneficial applications for aspects including nutrient and greenhouse gas budgeting. However, no practical methods exist to quantify mixing. We investigated if measuring element concentrations in: (A) fresh manure, (B) base material, and (C) pen manure offers a promising method to quantify manure/base mixing on pen surfaces. Using three operational beef feedlots as study sites, we targeted carbon (C), and silicon ( $\mathrm{Si}$ ), which are the two most abundant and easily measurable organic and inorganic elements. Our results revealed that $\mathrm{C}$ concentrations were strongly ( $>15$ times) and significantly $(P<0.05)$ higher whereas Si concentrations strongly $(>10$ times $)$ and significantly $(P<0.01)$ lower in fresh manure than base material at all three sites. These relative concentrations were not significantly impacted by manure decay, as determined by an 18-week incubation experiment. This suggested that both of these elements are suitable markers for quantifying base/manure mixing on pens. However, due to the chemical change of manure during decay, $\mathrm{C}$ was shown to be an imprecise marker of base/manure mixing. By contrast, using Si to estimate base/manure mixing was largely unaffected by manure decay. These findings were confirmed by measuring $\mathrm{C}$ and Si concentrations in stockpiled pen surface manure from one of the sites. Using Si concentrations is a promising approach to quantify base/manure mixing on feed pens given that this element is abundantly concentrated in soils and rocks.
\end{abstract}

Additional keywords: beef cattle, carbon, feedlots, manure, rock, silicon, soil.

Received 19 August 2014, accepted 28 January 2015, published online 1 May 2015

\section{Introduction}

Beef feedlots are used for finishing cattle from pastures, particularly in the USA, Canada and Australia. In Australia it is estimated that $5 \%$ of the total beef cattle population ( 23 million) is on feedlots at any time (Australian-Govt 2012). In the USA, $\sim 20$ million cattle are raised on feedlots annually (Rogge et al. 2006). Feedlot pens directly overlay native soil or a base of imported crushed rock material, often in the absence of bedding material.

Although feed pen surfaces have been reported to be dominated by manure (Durso et al. 2011), they may contain significant quantities of base rock/soil (herein referred to as base material) (Larney et al. 2006; García et al. 2012). No practical methods exist for quantifying base material/manure mixing on pen surfaces. Uncertainty regarding the extent of base material mixing with manure causes mass balance problems in fields such as nutrient and carbon (C) budgeting (Dantzman et al. 1983; Eghball et al. 1997), and greenhouse gas emission measurement where emissions from pad manure are often reported on a manure weight basis without necessarily accounting for the amount of soil/rock mixed in with it (Hao et al. 2001; Pattey et al. 2005). Indeed, the need for quantifying base material mixing with manure on feedlots has arisen in studies examining in situ soil profiles in feedlot pens (Mielke et al. 1974; Dantzman et al. 1983;
Berry and Miller 2005; García et al. 2012) as well as investigations into characterising manure hauled from feedlot pens (Larney et al. 2000; Rogge et al. 2006).

Using a marker element displaying a strong concentration contrast in base material relative to manure, or vice versa, could provide a useful approach to quantify mixing and assist with resolving this problem. Carbon is the most abundant and easily measurable organic element. Carbon concentrations in beef cattle manures have been reported to range between 34\% (Hao et al. 2001) and 46\% dry weight (Helgason et al. 2005) whereas $\mathrm{C}$ concentrations in topsoils generally range from $1.5 \%$ (Cremers et al. 2001) to $8.5 \%$ (Tate et al. 2007) dry weight with an average concentration of $2.5 \%$ dry weight (Shacklette and Boerngen 1984).

The most abundant inorganic element is silicon $(\mathrm{Si})$ whose global-scale soil/rock concentration has been reported to be 27\% dry weight (Shacklette and Boerngen 1984; Faure 1998). Only one study was found reporting beef cattle manure Si concentrations [9.5\% dry weight by Kobayashi et al. (2008)]. It is unclear whether this was fresh manure or pen manure.

The large manure/soil concentration differences for $\mathrm{C}$ and $\mathrm{Si}$, initially suggest that both these elements could offer a practical opportunity to quantify mixing on pen surfaces. To use this concentration contrast to evaluate mixing ratios, sampling and 
analysis of three representative materials would be required at a given feedlot: (A) fresh manure, (B) underlying base material; and (C) pen surface material, (which contains fresh and degraded manure as well as base material). In this work we assess if measuring $\mathrm{C}$ and $\mathrm{Si}$ concentrations offers a promising approach to quantify base/manure mixing on beef feedlot pen surfaces.

\section{Methods}

\section{Study sites, sample collection and preparation}

The three feedlots are located on the Darling Downs, $150 \mathrm{~km}$ west of Brisbane, Australia. Site A's herd size is 17000 with a stocking density of $15 \mathrm{~m}^{2} /$ head. Feed materials include barley and sorghum. The feedlot pens are constructed on soils native to the region (i.e. black Vertosol derived from weathering of mafic parent material). Manure from the pens is worked into a mound in the middle of the pen and removed every 4-6 months to a stockpiling site. Site B has an average herd size of 28000 with a stocking density of $15 \mathrm{~m}^{2} /$ head. The cattle receive a mixed ration diet comprising $\sim 65 \%$ grain with the remainder consisting of wet distiller's grain (ethanol byproduct), molasses, and cotton products. Site C's herd size is 26000 with a stocking density of 9-12 $\mathrm{m}^{2} /$ head. Diet includes molasses, wheat, barley, sorghum, corn silage, cereal silage, cotton seed, cotton seed hulls, cotton seed meal, cereal hay, and sorghum. The pens at Site B and C overlie crushed rock from local quarries (alluvial weathered basalt at Site $\mathrm{B}$ and $\mathrm{Ca}-\mathrm{Mg}$ rich conglomerate at Site C). Manure from the pens at these feedlots is scraped out every few weeks using a box scraper.

We were permitted access to one pen at each of the three sites. A 1-kg composite sample of fresh manure, observed to be deposited at the time of sampling, was collected from each site. These manure subsamples were taken from at least five deposits at each site. Care was taken to avoid scraping pen manure into the fresh samples. One-kilogram samples of the base material (i.e. soil for Site A and rock for Sites B and C) from each feedlot were obtained using material combined from six cores (to $20 \mathrm{~cm}$ depth) at each site. In addition to the fresh manure samples and soil/rock samples, a 1-kg composite manure sample was collected from a $250-\mathrm{m}^{3}$ stockpile of manure scraped from the pens at Site A. The composite sample was acquired from six cored subsamples at a depth of $1.5 \mathrm{~m}$ in the 1-day-old pile; with each core extracting $\sim 150 \mathrm{~g}$ of manure. Each material was homogenised using a mechanical mixer. Batches of each material were collected and refrigerated for further experimentation and analysis.

\section{Fresh manure decay experiment}

Five-hundred grams (wet weight) of homogenised fresh manure from Sites A and B, and $250 \mathrm{~g}$ of manure from Site C (where less fresh manure was available), was split into 12 equal-weight batches. These batches were loosely packed into $50-\mathrm{mL}$ opentopped plastic containers. These were placed inside a $35^{\circ} \mathrm{C}$ incubator in order to assess dry mass loss from manure under warm conditions: optimal for respiration rates in manures and soils (Sikora and Sowers 1985; Murwira et al. 1990; Keith et al. 1997). The containers were left in the incubator for 18 weeks (126 days), i.e. the average maximum clean-out period for manure on pens in Queensland (Skerman 2004) and representative of typical clean-out periods for pens in the USA (Dantzman et al. 1983). The experiment represents a decay simulation for pendeposited manure with the aim to estimate the impact of decay on manure $\mathrm{C}$ and $\mathrm{Si}$ concentrations.

Deionised (to avoid possible elemental contamination) water was used to adjust manure moisture contents between almost dry ( $<5 \%$ by dry weight) and starting levels, which would be expected under field conditions. Manure batches were removed from the incubator at regular intervals (see Fig. 1 for timing), as sacrificial replicates, and measured for their dry matter content by oven-drying the samples overnight at $105^{\circ} \mathrm{C}$ and recording weight loss. In addition to the above, sacrificial replicates of each manure were taken from the incubator and set aside for chemical analysis at various times (see Results and Discussion for timing).

\section{Chemical analyses}

Chemical analyses were performed on manure and soil/rock samples. Total (Dumas) C was analysed using a Leco analyser following the Dumas dry combustion principle where samples are combusted at $1050^{\circ} \mathrm{C}$. This method has been well described in previous work (Buckee 1994). X-ray fluorescence spectroscopy was used to analyse for $\mathrm{Si}$ concentrations in the samples. Chemical analyses were performed in triplicate on the fresh manure, the stockpiled manure from Site A and soil/rock samples from each site.

\section{Quality control}

Lower detection limits for the elemental analyses conducted in this study are presented in Table 1. The table also shows recoveries of element concentrations for reference standard samples analysed by the laboratory.

\section{Statistical analyses}

Expanded regression (GENSTAT) was used to determine means of the manure $\mathrm{C}$ and $\mathrm{Si}$ concentrations at time 0 , half way

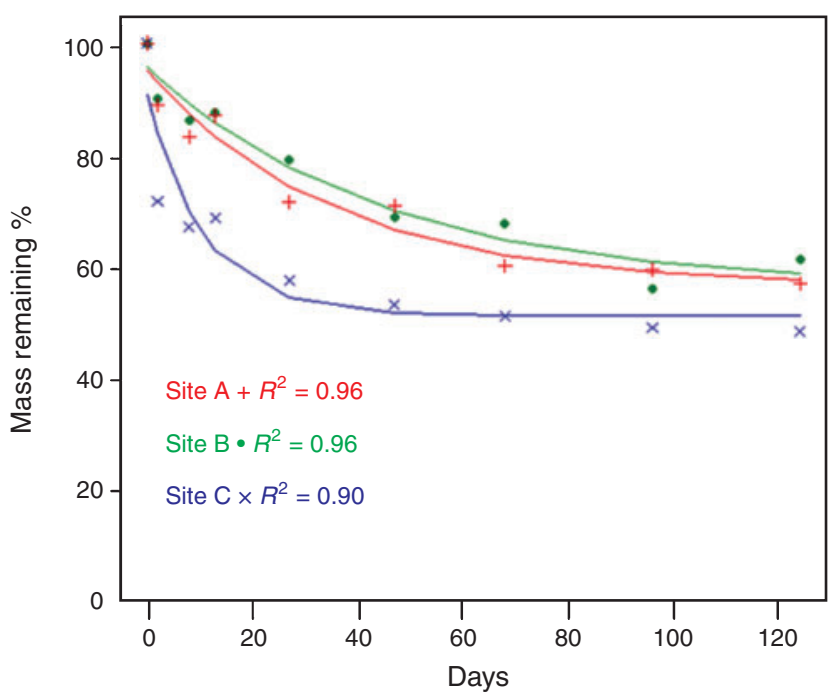

Fig. 1. Mass loss due to biological decay for fresh manures. Points are sacrificial replicates; decay curves fitted using classic decay equation. $R^{2}$ values show correlation of empirical data to equation. 
through the decay experiment (63 days) and at the end (126 days). ANOVA was then applied to the data to determine the statistical significance of the differences in relative concentrations of elements between the manure and the soil/rock across all three sites. A $P$-value of $<0.05$ was considered significant. Confidence intervals (CI) to describe the variability in element concentrations during decay were determined using Excel, employing the equation:

$$
\text { CI upper, lower }= \pm 1.96 \times(\text { s.d. } / \sqrt{ } \mathrm{n})
$$

Where, s.d. $=$ standard deviation, $n=$ sample number, and 1.96 is the critical value for the $95 \% \mathrm{CI}$.

\section{Results and discussion}

Dry mass losses for each of the manures during the incubation are plotted in Fig. 1. Manures from all three feedlots lost $\sim 40-50 \%$ of their dry mass (Fig. 1).

Mass loss for each manure type was well described by the classic exponential decay model. Most mass loss (>two-thirds) occurred in the first month, demonstrating that the composition of manure deposited on feedpads can change rapidly. In order to assess how biological decay affected the manures' composition, we recorded $\mathrm{C}$ and $\mathrm{Si}$ concentrations at various times during the decay experiment. The data is presented in Table 1. Changes in $\mathrm{C}$ concentrations during decay were significant $(P<0.05)$.
Carbon values tended to increase initially and then fall back to initial levels (Table 2). This trend might seem surprising as substantial $\mathrm{C}$ losses from manure have been reported during decay and composting processes (Kirchmann and Witter 1992; Larney et al. 2005). Yet, in this study the manure's starting C concentrations were greater than typical carbohydrate $\mathrm{C}$ concentrations (40\%). Thus, it makes sense that as carbohydrates in manure are initially consumed for respiration the overall manure $\mathrm{C}$ concentration would go up. This would be exacerbated by the loss of other volatiles with even lower $\mathrm{C}$ contents, such as urea, ammonia, and fermentation products all of which have been reported in cattle manure (Miller and Varel 2002; Cole et al. 2005; Pratt et al. 2014). Later during decay, as more complex $\mathrm{C}$ compounds are consumed in biological processes and the ash content increases relative to the volatile content, manure $\mathrm{C}$ concentrations would drop, which was observed in our work.

Silicon concentrations tended to increase during decay (Table 2), which was expected given that it is a non-volatile element; although Si concentration changes were not significant $(P>0.05)$. Using the elemental concentrations of the base material given in Table 3 and the manure data in Table 2, we calculated differences in relative concentrations of elements between the manure and the soil/rock across all three sites (Table 4). The relative concentration ratios are expressed as enrichments in base material relative to manure for $\mathrm{Si}$

Table 1. Quality control data for element analyses

\begin{tabular}{lcccc}
\hline Element & $\begin{array}{c}\text { Lower detection } \\
\text { limit } \%\end{array}$ & $\begin{array}{c}\text { Reference sample 1 } \\
-\% \text { deviation from } \\
\text { target concentration }\end{array}$ & $\begin{array}{c}\text { Reference sample 2 } \\
-\% \text { deviation from } \\
\text { target concentration }\end{array}$ & $\begin{array}{c}\text { Reference sample 3 } \\
-\% \text { deviation from } \\
\text { target concentration }\end{array}$ \\
\hline Carbon & 0.01 & 5.3 & 5.0 & 0.3 \\
Silicon & 0.01 & 3.9 & 4.0 & 3.8 \\
\hline
\end{tabular}

Table 2. Concentrations of carbon and silicon in the studied manures, as affected by biological decay (reported on a dry weight basis) for sacrificial replicate samples

Laboratory error given in parentheses. IS, insufficient sample for analyses

\begin{tabular}{|c|c|c|c|c|c|c|c|}
\hline & \multirow[t]{2}{*}{ Site } & \multicolumn{5}{|c|}{ Days } & \multirow[t]{2}{*}{ Significance of change } \\
\hline & & 0 & 12 & 26 & 67 & 126 & \\
\hline \multirow[t]{3}{*}{ Carbon \% } & A & $41.5(1.47)$ & $53.3(1.88)$ & 47.9 (1.69) & $41.2(1.46)$ & $41.2(1.46)$ & - \\
\hline & B & $44.2(1.56)$ & $44.9(1.59)$ & $49.7(1.76)$ & $41.7(1.47)$ & $42.2(1.49)$ & $P<0.05$ \\
\hline & $\mathrm{C}$ & $41.5(1.47)$ & $68.4(2.42)$ & $48.5(1.71)$ & $43.4(1.53)$ & $43.6(1.54)$ & - \\
\hline \multirow[t]{3}{*}{ Silicon \% } & A & $1.84(0.07)$ & $1.91(0.07)$ & $2.02(0.08)$ & IS & $2.53(0.10)$ & - \\
\hline & B & $0.54(0.02)$ & $0.97(0.04)$ & $1.29(0.05)$ & IS & $1.15(0.04)$ & None \\
\hline & $\mathrm{C}$ & $1.02(0.04)$ & $0.92(0.04)$ & $1.05(0.04)$ & IS & $1.42(0.06)$ & - \\
\hline
\end{tabular}

Table 3. Composition of base material at the studied sites

Average values of triplicate analyses. Laboratory error given in parentheses for means

\begin{tabular}{lcccccc}
\hline & Mean & $\begin{array}{c}\text { Site A } \\
\text { Relative standard } \\
\text { deviation\% of mean }\end{array}$ & Mean & $\begin{array}{c}\text { Site B } \\
\text { Relative standard } \\
\text { deviation \% of mean }\end{array}$ & Mean & $\begin{array}{c}\text { Site C } \\
\text { Relative standard } \\
\text { deviation \% of mean }\end{array}$ \\
\hline Carbon \% & $2.39(0.08)$ & 2 & $0.08(<0.01)$ & 26 & $1.15(0.04)$ & 1 \\
Silicon \% & $34.4(1.34)$ & 2 & $38.0(1.48)$ & 4 & $20.3(0.79)$ & 1 \\
\hline
\end{tabular}


(i.e. base material element concentration/manure element concentration) and vice versa for $\mathrm{C}$ (i.e. manure element concentration/base material element concentration).

Based on data in Table 4 it appears that the strong relative concentration differences in $\mathrm{C}$ and $\mathrm{Si}$ between manure and base materials are not impacted by manure decay and, thus, both of these elements could be effectively used to estimate mixing on feedlot pen surfaces. However, it is important not only to consider how manure decay affects relative concentrations but also how it affects the application of these contrasts to quantify

Table 4. Concentration ratios for silicon and carbon between base material and manure across sites over time Calculated from the rock/soil means in Table 3 and the fitted means of manure concentrations in Table 2 determined using expanded regression (GENSTAT)

\begin{tabular}{|c|c|c|c|c|c|c|}
\hline \multirow[t]{2}{*}{ Element } & \multirow[t]{2}{*}{ Site } & \multicolumn{3}{|c|}{ Concentration ratio } & \multirow{2}{*}{$\begin{array}{l}\text { Significance } \\
\text { of contrast }\end{array}$} & \multirow{2}{*}{$\begin{array}{l}\text { Average concentration ratio } \\
\text { across site and days }\end{array}$} \\
\hline & & Day 0 & Day 63 & Day 126 & & \\
\hline \multirow[t]{3}{*}{ Carbon } & A & 19.8 & 18.9 & 17.0 & $P<0.01$ & 200 \\
\hline & B & 576 & 549 & 495 & $P<0.05$ & \\
\hline & $\mathrm{C}$ & 44.4 & 42.5 & 38.7 & $P<0.01$ & \\
\hline \multirow[t]{3}{*}{ Silicon } & A & 19.0 & 14.5 & 14.3 & $P<0.01$ & 19.6 \\
\hline & B & 52.7 & 29.6 & 28.9 & $P<0.01$ & \\
\hline & $\mathrm{C}$ & 24.3 & 14.5 & 14.2 & $P<0.01$ & \\
\hline
\end{tabular}

Site A

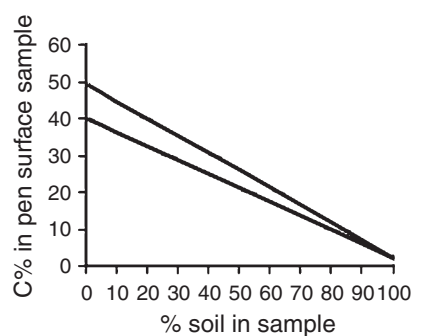

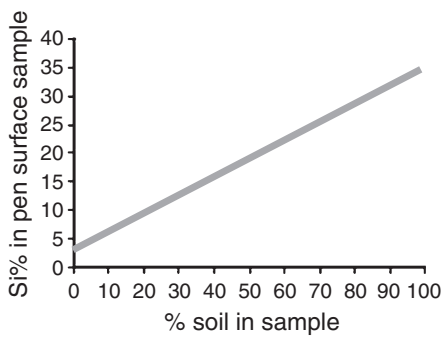

Site C

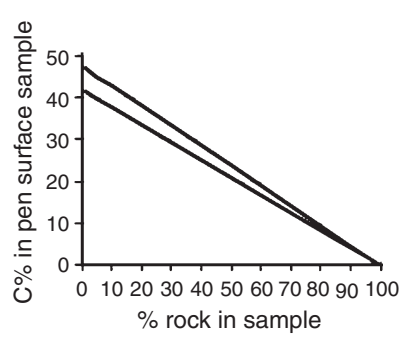

Site B
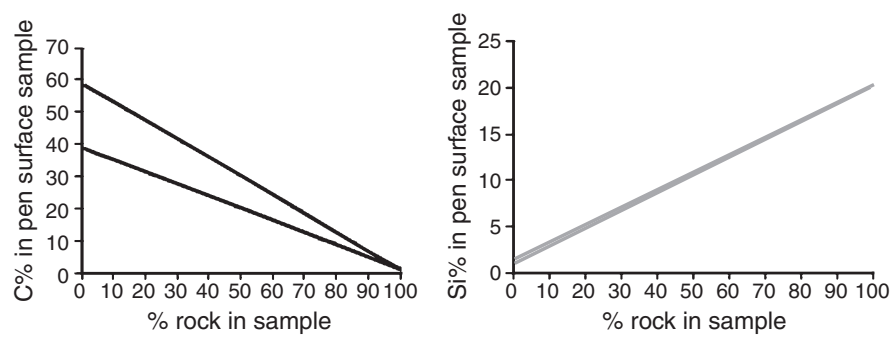

Fig. 2. Models depicting percentage of rock/soil material mixed with manure on pen surfaces as a function of carbon and silicon in hypothetical pen manure samples at the three studied sites. The two lines in each graph represent upper and lower variability ( $95 \%$ confidence level) in manure concentrations as affected by decay.
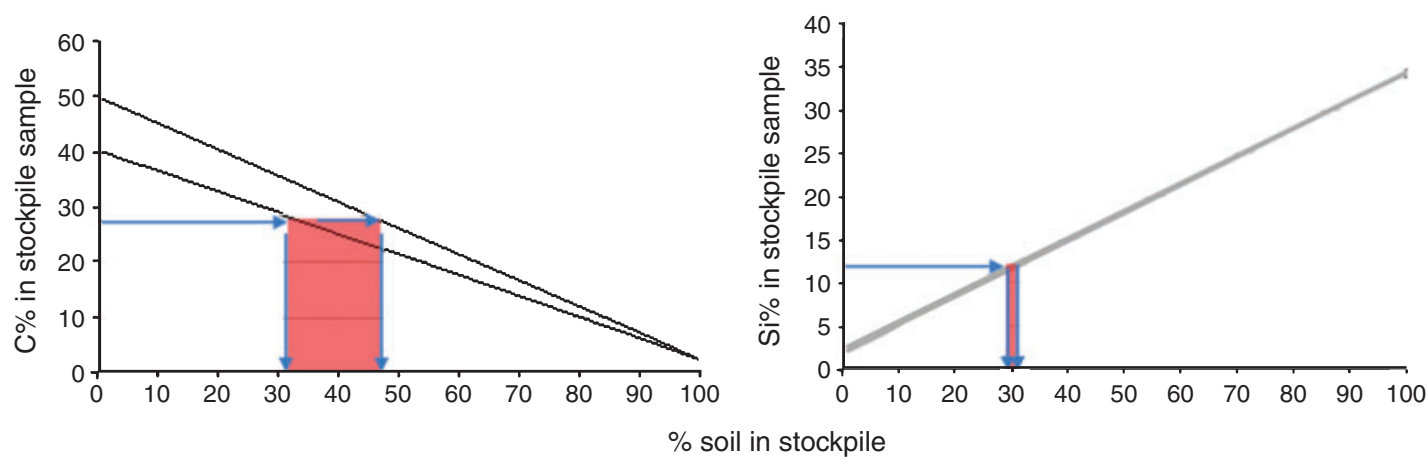

Fig. 3. Applying the mixing model for Site A to estimate the proportion of soil mixed into a stockpile of pen manure from that site. 
manure/base material mixing. To investigate this, we developed simple mixing models using our data (Fig. 2). The ratio of fresh to fully decayed manure in a given feed pen surface sample will likely be a continuum between the two extremes. In our models we represent this uncertainty by plotting upper and lower estimates of manure/base material mixing relationships using the width of the two-tail CI (95\%) in element concentrations observed in the decay trial using Eqn 1.

It is evident that the precision of quantifying base material/ manure mixing using $\mathrm{C}$ concentrations is poor, due to the effect of manure decay on $\mathrm{C}$ concentrations (Fig. 2). By contrast, Si yields a more precise estimate of base material/manure mixing on pen surfaces at each site (Fig. 2). To check our model approach, we applied $\mathrm{C}$ and $\mathrm{Si}$ concentrations measured in stockpiled manure from the pen surfaces at Site A to the mixing model generated for that site (Fig. 3). The average C and $\mathrm{Si}$ concentrations in the triplicate stockpile samples were $27 \%(\mathrm{RSD}=2 \%)$ and $10.5 \%(\mathrm{RSD}=10 \%)$ on a dry weight basis. It can be seen that using both elements yielded good agreement regarding the amount of soil $(\sim 30 \%)$ mixed in with the pen manure (Fig. 3). However, the precision using $\mathrm{C}$ concentrations was much poorer than that given by using $\mathrm{Si}$ concentrations (Fig. 3). The high proportion of base soil in the pen manure highlights the importance of quantifying manure/base mixing.

Although the current demonstration is based on limited data (three sites) we suggest that the use of $\mathrm{Si}$ concentrations quantify manure/base material mixing has widespread potential given the global concentration of $\mathrm{Si}$ in rocks and soils. Aluminium would be another potentially strong marker element given the literature shows vastly greater soil/rock $\mathrm{Al}$ contents on a global scale (Shacklette and Boerngen 1984; Faure 1998) compared with beef manure (Eghball and Power 1993; Chen et al. 2003; Ajiboye et al. 2004; Miller et al. 2013). In some locations, notably limestone landscapes, which are dominated by $\mathrm{Ca}, \mathrm{Mg}$ and $\mathrm{C}, \mathrm{Si}$ and $\mathrm{Al}$ would not be useful markers for estimating base/manure mixing on feedlots. In these cases background research could point to the use of other suitable element markers (e.g. $\mathrm{Ca}, \mathrm{Mg}$ ) to estimate base/manure mixing.

\section{Conclusions}

Our study showed that measuring $\mathrm{Si}$ concentrations offers a promising and simple method for quantifying manure/base material on beef feedlot pen surfaces. Based on our findings, as well as literature data, we suggest that this method has widespread potential due to the abundant global concentration of $\mathrm{Si}$ in soils and rocks. By contrast, using carbon and organic compounds to estimate mixing is not recommended because they are affected too much by manure decay. Accurate quantification of base material mixing with manure on pen surfaces will assist in fields such as greenhouse gas and nutrient budgeting within beef feedlots.

\section{Acknowledgements}

This research was funded by the Australian Government, University of Queensland, Meat and Livestock Australia, Australian Pork Limited, Rural Industries Research and Development Corporation and Australian Egg Corporation Limited as part of the National Agricultural Manure Management Program. We are grateful for advice from Janine Price, Ray
King and Ian Kruger. Thanks to David Mayer for statistical analysis and Jarl Devereux for sampling and analysis assistance.

\section{References}

Ajiboye B, Akinremi OO, Racz GJ (2004) Laboratory characterization of phosphorus in fresh and oven-dried organic amendments. Journal of Environmental Quality 33(3), 1062-1069. doi:10.2134/jeq2004.1062

Australian-Govt (2012) Australian National Greenhouse Accounts - National Inventory Report 2010 Volume 1. (Canberra)

Berry ED, Miller DN (2005) Cattle feedlot soil moisture and manure content: cattle feedlot soil moisture and manure content: II. Impact on Escherichia coli O157. Journal of Environmental Quality 34(2), 656-663. doi:10.2134/jeq2005.0656

Buckee GK (1994) Determination of total nitrogen in barley, malt and beer by Kjeldahl procedures and the Dumas combustion method: collaborative trial. Journal of the Institute of Brewing. Institute of Brewing (Great Britain) 100(2), 57-64.

Chen S, Harrison JH, Liao W, Elliott DC, Liu C, Brown MD, Wen Z, Solana AE, Kincaid RL, Stevens DJ (2003) Value-Added Chemicals from Animal Manure, Department of Energy, USA. (Springfield, VA)

Cole NA, Clark RN, Todd RW, Richardson CR, Gueye A, Greene LW, Mcbride K (2005) Influence of dietary crude protein concentration and source on potential ammonia emissions from beef cattle manure 123 . Journal of Animal Science 83(3), 722-731.

Cremers DA, Ebinger MH, Breshears DD, Unkefer PJ, Kammerdiener SA, Ferris MJ, Catlett KM, Brown JR (2001) Measuring total soil carbon with Laser-Induced Breakdown Spectroscopy (LIBS). Journal of Environmental Quality 30(6), 2202-2206. doi:10.2134/jeq2001.2202

Dantzman CL, Richter MF, Martin FG (1983) Chemical elements in soils under cattle pens. Journal of Environmental Quality 12(2), 164-168. doi:10.2134/jeq1983.00472425001200020002x

Durso LM, Harhay GP, Smith TP, Bono JL, Desantis TZ, Clawson ML (2011) Bacterial community analysis of beef cattle feedlots reveals that pen surface is distinct from feces. Foodborne Pathogens and Disease 8(5), 647-649. doi:10.1089/fpd.2010.0774

Eghball B, Power JF (1993) Management of manure from beef cattle in feedlots and from minor classes of livestock, United States Department of Agriculture. (Washington, DC)

Eghball B, Power JF, Gilley JE, Doran JW (1997) Nutrient, carbon, and mass loss during composting of beef cattle feedlot manure. Journal of Environmental Quality 26(1), 189-193. doi:10.2134/jeq1997.004724 $25002600010027 \mathrm{x}$

Faure G (1998) 'Principles and applications of geochemistry.' 2nd edn. (Prentice-Hall Inc.: Upper Saddle River, NJ)

García AR, Maisonnave R, Massobrio MJ, Fabrizio De Iorio AR (2012) Field-scale evaluation of water fluxes and manure solution leaching in feedlot pen soils. Journal of Environmental Quality 41(5), 1591-1599. doi:10.2134/jeq2011.0320

Hao X, Chang C, Larney FJ, Travis GR (2001) Greenhouse gas emissions during cattle feedlot manure composting Lethbridge Research Centre Contribution No. 3870031. Journal of Environmental Quality 30(2), 376-386. doi:10.2134/jeq2001.302376x

Helgason BL, Larney FJ, Janzen HH (2005) Estimating carbon retention in soils amended with composted beef cattle manure. Canadian Journal of Soil Science 85(1), 39-46. doi:10.4141/S04-049

Keith H, Jacobsen KL, Raison RJ (1997) Effects of soil phosphorus availability, temperature and moisture on soil respiration in Eucalyptus pauciflora forest. Plant and Soil 190(1), 127-141. doi:10.1023/ A:1004279300622

Kirchmann H, Witter E (1992) Composition of fresh, aerobic and anaerobic farm animal dungs. Bioresource Technology 40(2), 137-142. doi:10.1016/0960-8524(92)90199-8

Kobayashi N, Morioka M, Komiyama T, Ito T, Saigusa M (2008) Silicon content in livestock manure compost and a simple estimation method for 
it (in Japanese with English summary). Journal of the Japan Society of Waste Management Experts 19, 150-154. doi:10.3985/jswme.19.150

Larney FJ, Olson AF, Carcamo AA, Chang C (2000) Physical changes during active and passive composting of beef feedlot manure in winter and summer. Bioresource Technology 75(2), 139-148. doi:10.1016/ S0960-8524(00)00040-7

Larney FJ, Ellert BH, Olson AF (2005) Carbon, ash and organic matter relationships for feedlot manures and composts. Canadian Journal of Soil Science 85(2), 261-264. doi:10.4141/S04-060

Larney FJ, Buckley KE, Hao X, Mccaughey WP (2006) Fresh, stockpiled, and composted beef cattle feedlot manure. Journal of Environmental Quality 35(5), 1844-1854. doi:10.2134/jeq2005.0440

Mielke LN, Swanson NP, Mccalla TM (1974) Soil profile conditions of cattle feedlots. Journal of Environmental Quality 3(1), 14-17. doi:10.2134/ jeq1974.00472425000300010004x

Miller DN, Varel VH (2002) An in vitro study of manure composition on the biochemical origins, composition, and accumulation of odorous compounds in cattle feedlots. Journal of Animal Science 80(9), 2214-2222.

Miller JJ, Beasley B, Drury C (2013) Transport of metals (Al, Fe) and trace elements $(\mathrm{Cu}, \mathrm{Mo}, \mathrm{Ni}$, and $\mathrm{Zn})$ through intact soil cores amended with fresh or composted beef cattle manure for nine years. Compost Science \& Utilization 21(2), 99-109. doi:10.1080/1065657X.2013. 836067

Murwira HK, Kirchmann H, Swift MJ (1990) The effect of moisture on the decomposition rate of cattle manure. Plant and Soil 122(2), 197-199. doi:10.1007/BF02851975
Pattey E, Trzcinski MK, Desjardins RL (2005) Quantifying the reduction of greenhouse gas emissions as a result of composting dairy and beef cattle manure. Nutrient Cycling in Agroecosystems 72(2), 173-187. doi:10.1007/s10705-005-1268-5

Pratt C, Redding M, Hill J, Mudge SR, Westermann M, Paungfoo-Lonhienne C, Schmidt S (2014) Assessing refrigerating and freezing effects on the biological/chemical composition of two livestock manures. Agriculture, Ecosystems \& Environment 197, 288-292. doi:10.1016/j.agee.2014. 08.012

Rogge WF, Medeiros PM, Simoneit BRT (2006) Organic marker compounds for surface soil and fugitive dust from open lot dairies and cattle feedlots. Atmospheric Environment 40(1), 27-49. doi:10.1016/ j.atmosenv.2005.07.076

Shacklette HT, Boerngen J (1984) Element concentrations in soils and other surficial materials of the conterminous United States. US Geological Survey. (United States Government Printing Office: Washington, DC)

Sikora LJ, Sowers MA (1985) Effect of temperature control on the composting process1. Journal of Environmental Quality 14(3), 434-439. doi:10.2134/jeq1985.00472425001400030025x

Skerman A (2004) Reference manual for the establishment and operation of beef cattle feedlots in Queensland. Queensland, Australia, Department of Primary Industries and Fisheries. (Brisbane)

Tate KR, Ross DJ, Saggar S, Hedley CB, Dando J, Singh BK, Lambie SM (2007) Methane uptake in soils from Pinus radiata plantations, a reverting shrubland and adjacent pastures: effects of land-use change, and soil texture, water and mineral nitrogen. Soil Biology and Biochemistry 39(7), 1437-1449. doi:10.1016/j.soilbio.2007.01.005 